\title{
Light traps for sampling marine biodiversity
}

\author{
Laura E. McLeod and Mark J. Costello*
}

\begin{abstract}
Standardised sampling methods are required to meet the Convention on Biological Diversity Aichi Targets to monitor trends in biodiversity. Currently the animals monitored in the marine environment are predominantly vertebrates and surface plankton, but arthropods (especially benthic crustaceans) make up a third of marine species, provide an important link in the food web and are under sampled. Sampling these animals with light traps on the benthos in structurally complex areas would fill a gap in biological monitoring. A survey of the literature of light-trap designs showed they collected at least 12 phyla of benthic and planktonic animals, and 13 orders of crustaceans. These traps can be deployed anywhere from an hour to overnight and on the seabed or in the water column. They can be low cost, have low environmental impact and be used in complex and fragile habitats otherwise difficult to sample. Environmental factors, such as water movement and turbidity, as well as trap design and method of deployment, may affect catch. Experimental field tests are required to develop the use of light-traps as a standard method for marine biodiversity monitoring, including design, deployment, and replication.
\end{abstract}

Keywords: Light traps, Biodiversity, Monitoring, Demersal, Plankton, Benthos, Macrofauna, Crustacea, Fish

\section{Background}

Methods for monitoring trends in biodiversity are urgently required by the Convention on Biological Diversity's Aichi Targets to help stem the decline of biodiversity worldwide [1]. To facilitate this, Pereira et al. [2] proposed the implementation of Essential Biodiversity Variables. One of these proposed EBVs is to measure species population abundances. This would require, "Counts or presence surveys for groups of species easy to monitor or important for ecosystems, over an extensive network of sites, complemented with incidental data" [2]. These EBVs should be sensitive to change, technically feasible, economically viable and sustainable in time [2-4].

Most current marine sampling is centred on vertebrates that either have commercial importance (i.e., fishes) or intrinsic appeal (i.e., birds and marine mammals) [3]. Although chordates only make up $11 \%$ of the oceans known species, they are disproportionately sampled and comprise over $60 \%$ of the records in the Ocean

*Correspondence: m.costello@auckland.ac.nz Institute of Marine Science, University of Auckland, Auckland 1142, New Zealand
Biogeographic Information System (OBIS) [5]. Arthropods and molluscs on the other hand account for over half of all marine species, but make up only $26 \%$ of the OBIS records. One of the notable contributors to invertebrate sampling is the Continuous Plankton Recorder, which has repeatedly collected surface plankton across oceans for over 80 years [6]. However, as its sampling is limited to the surface waters of the open ocean it gathers a rather narrow range of species. While there were 12 phyla identified, over $65 \%$ of the species identified were calanoid copepods [7-9]. Many of the wider array of species in the ocean that form the base of the food web are monitored substantially less due to sampling costs and effort. Macrofaunal invertebrates are a key link between primary production and the rest of the food web, providing prey for birds, fish and shellfish [10-14]. They often inhabit structurally complex habitats like reefs, epifaunal turfs, and vegetation which are difficult to sample without damaging the habitat (Table 1). Minimising habitat damage is especially important when sampling protected areas and biogenic habitats [15]. Thus a major component of marine food webs and biodiversity is largely overlooked in monitoring programmes. 
Table 1 Common invertebrate sampling techniques. Adapted from [3]

\begin{tabular}{|c|c|c|}
\hline Method & Organisms collected & Drawback \\
\hline Benthic core & Animals buried in the sediments & \multirow{4}{*}{$\begin{array}{l}\text { Destructive as habitat is removed in sampling. More } \\
\text { mobile animals escape. Time consuming to collect and } \\
\text { process samples. Specimens usually damaged during } \\
\text { collection }\end{array}$} \\
\hline Grab sample & & \\
\hline Dredge & Specimens at and just below surface & \\
\hline Quadrat scraping & Sessile animals on solid surface & \\
\hline Suction sampler & Benthic organisms & Destructive. Expensive equipment and labour intensive \\
\hline Plankton net or pump & Free floating and slow moving organisms & $\begin{array}{l}\text { Cannot sample in structurally complex areas. Specimens } \\
\text { can be damaged by net. More mobile taxa escape }\end{array}$ \\
\hline Visual including photography & $\begin{array}{l}\text { Observe larger mobile fauna and sessile and } \\
\text { sedentary macrobiota }\end{array}$ & Mobile macrofauna not sampled \\
\hline Baited traps & Larger mobile macrofauna & $\begin{array}{l}\text { Limited to scavenging species and will attract megafauna } \\
\text { that predate smaller species }\end{array}$ \\
\hline Artificial substrata & Sessile, sedentary and nestling biota & Have to be left in situ for weeks to months to be colonised \\
\hline Emergence and sediment traps & $\begin{array}{l}\text { Select benthic animals that move up or down in } \\
\text { water column }\end{array}$ & $\begin{array}{l}\text { Need to be large to capture sufficient number of animals } \\
\text { and/or left in place for days }\end{array}$ \\
\hline
\end{tabular}

The light trap's passive sampling, retention of live specimens, and low cost, has made it widely used for sampling insect diversity in terrestrial environments [16]. For example, light traps have been used consistently and extensively for standardized mosquito monitoring since the 1940s [17-19] and for monitoring moths and other species considered as pests [20, 21]. The advantages that light traps bring to terrestrial sampling may also make them useful for monitoring marine invertebrates. Although light traps have been used underwater, a standard trap and methodology has not been developed for monitoring invertebrates. Here we review the use of light-traps in the marine environment, and assess their potential as a standard method for monitoring biodiversity.

\section{Uses}

In the marine environment light traps have had a few purposes: to complement plankton tows in collecting organisms that may avoid tows (e.g., late stage larval fishes); to sample organisms with minimal damage for ease of identification and inclusion in reference collections of specimens; to collect live organisms for research (e.g., [22]) and teaching (authors unpublished); and for collection in areas where plankton nets may cause damage to sensitive species (e.g., corals) or be damaged by structurally complex habitats (e.g., rocky reefs) [23]. As passive sampling methods, light traps are useful when multiple locations need to be sampled simultaneously [24]. Light traps were also developed for deploying on salmon farms in an attempt to reduce copepod parasite infestations but were not commercially successful [25-28].

Most commonly, light traps have been used in coral reef environments [23] as their static nature gives them an advantage over towed equipment in these sensitive areas. However, their uses have also been explored in temperate waters [29-31], tropical mangroves [32], and Antarctic ice flows [33]. Although most often used to collect larval fishes (over 100 families and 324 species, Additional file 1: Table S1), they have also collected invertebrates from over 12 phyla (Table 2). Crustaceans comprise the greatest richness of invertebrate species collected (Table 3) with at least 128 different species reported (Additional file 1: Table S2). Light traps have also been used for monitoring crab and lobster recruitment $[30,34,35]$.

\section{Design and construction}

In 94 papers reviewed we found there were 49 original designs, with many more including modifications of previous designs. Designs ranged from very basic and inexpensive 1-2 L tube (bottle) traps with funnel entrances to a $240 \mathrm{~L}$ box trap with pulsing lights (Fig. 1). Larger traps are more difficult to handle and can be more expensive to construct. The only comparison between trap sizes found the smaller (box) traps had a similar or greater catch of fish and invertebrates than the larger [36]. The most common designs were a form of box trap with tapered entrances on four sides. They can have adjustable entrance slots [37], multiple chambers [23, 24], and a cod-end for catching and filtering the organisms as the trap is removed. Flat sided traps may suffer from inefficiencies in capturing organisms as some animals that are attracted to the light may never find the entrances [38]. The quatrefoil trap was designed to mitigate this problem [39]. Its shape resembles a four lobed cloverleaf with each side leading to an entrance that directs attracted animals into the trap. One study found the quatrefoil trap to collect significantly more larval fish than cylindrical and box 
Table 2 Higher taxa reported to have been collected in light traps in the marine environment. Where available, the number of species identified is given. $\mathrm{n} / \mathrm{a}=$ not available as only identified to phylum level. See Additional file 1: Tables S1 and S2 for detailed list of taxa

\begin{tabular}{|c|c|c|}
\hline Phylum & Number species & References \\
\hline Annelida, Polychaeta & 1 & $\begin{array}{l}\text { Zismann [94], Jones [46], Fincham [55], Sale et al. [88], Smith et al. [90], Tranter et al. [93], Kawaguchi et al. [33], } \\
\text { Meekan et al. [36, 38], Carleton et al. [75], Granek and Frasier [32], Mwaluma et al. [40], Tor et al. [92] }\end{array}$ \\
\hline Arthropoda & 128 & $\begin{array}{l}\text { Zismann [94], Jones [46], Fincham [55], Smith et al. [90], Tranter et al. [93], Kawaguchi et al. [33], Holmes and } \\
\text { Jeal [82], Song and Yun [91], Meekan et al. [36, 38], Carleton et al. [75], Hovda and Fosshagen [54], Roegner } \\
\text { et al. [30], Granek and Frasier [32], Øresland [34], Herter and Eckert [81], Porter et al. [87], Mwaluma et al. } \\
\text { [40], Michel et al. [43], Tor et al. [92], Chang [76], Kim et al. [85], Sigurdsson et al. [89], Costello et al. [41] }\end{array}$ \\
\hline Chaetognatha & 1 & $\begin{array}{l}\text { Jones [46], Fincham [55], Smith et al. [90], Tranter et al. [93], Carleton et al. [75], Granek and Frasier [32], } \\
\text { Costello et al. [41] }\end{array}$ \\
\hline Cnidaria & 3 classes & Carleton et al. [75], Mwaluma et al. [40] \\
\hline Chordata & 320 & Carleton et al. [75] and Additional file 1: Table S1 \\
\hline Ctenophora & 1 & Carleton et al. [75] \\
\hline Echinodermata & $\mathrm{n} / \mathrm{a}$ & Carleton et al. [75] \\
\hline Hemichordata & $\mathrm{n} / \mathrm{a}$ & Carleton et al. [75] \\
\hline Mollusca & 6 & $\begin{array}{l}\text { Zismann [94], Fincham [55], Thorrold [60], Carleton et al. [75], Jackson et al. [83], Mwaluma et al. [40], Tor et al. } \\
\text { [92], Costello et al. [41] }\end{array}$ \\
\hline Nematoda & $\mathrm{n} / \mathrm{a}$ & Zismann [94], Costello et al. [41] \\
\hline Phoronida & $\mathrm{n} / \mathrm{a}$ & Carleton et al. [75] \\
\hline Platyhelminthes & One class & Carleton et al. [75], Costello et al. [41] \\
\hline Tunicata & 1 & Carleton et al. [75] \\
\hline
\end{tabular}

\section{Table 3 The higher taxa and number of species of marine crustaceans that have been collected in light traps}

\begin{tabular}{|c|c|c|}
\hline Class or order & Number of species & References \\
\hline Amphipoda & 27 & $\begin{array}{l}\text { Zismann [94], Jones [46], Fincham [55], Smith et al. [90], Tranter et al. [93], Kawaguchi et al. [33], Holmes } \\
\text { and Jeal [82], Meekan et al. [36, 38], Carleton et al. [75], Granek and Frasier [32], Mwaluma et al. [40], } \\
\text { Michel et al. [43], Tor et al. [92], Kim et al. [85], Sigurdsson et al. [89], Costello et al. [41] }\end{array}$ \\
\hline Cumacea & 24 & $\begin{array}{l}\text { Hale [50, 80], Zismann [94], Fincham [55], Smith et al. [90], Tranter et al. [93], Kawaguchi et al. [33], Carleton } \\
\text { et al. [75], Meekan et al. [36], Granek and Frasier [32], Tor et al. [92], Costello et al. [41] }\end{array}$ \\
\hline Decapoda & 17 & $\begin{array}{l}\text { Zismann [94], Jones [46], Fincham [55], Smith et al. [90], Tranter et al. [93], Meekan et al. [38], Carleton et al. } \\
\text { [75], Roegner et al. [30], Granek and Frasier [32], Øresland [34], Herter and Eckert [81], Porter et al. [87], } \\
\text { Mwaluma et al. [40], Tor et al. [92], Sigurdsson et al. [89], Costello et al. [41] }\end{array}$ \\
\hline Euphausiacea & 5 & $\begin{array}{l}\text { Jones [46], Fincham [55], Kawaguchi et al. [33], Meekan et al. [36, 38], Carleton et al. [75], Granek and } \\
\text { Frasier [32], Tor et al. [92], Sigurdsson et al. [89], Costello et al. [41] }\end{array}$ \\
\hline Isopoda & 2 & $\begin{array}{l}\text { Zismann [94], Jones [46], Fincham [55], Tranter et al. [93], Kawaguchi et al. [33], Holmes and Jeal [82], } \\
\text { Meekan et al. [36, 38], Carleton et al. [75], Granek and Frasier [32], Tor et al. [92], Sigurdsson et al. [89], } \\
\text { Costello et al. [41] }\end{array}$ \\
\hline Leptostraca & 1 & Tor et al. [92] \\
\hline Mysida & 4 & $\begin{array}{l}\text { Zismann [94], Jones [46], Fincham [55], Smith et al. [90], Kawaguchi et al. [33], Meekan et al. [36, 38], Carle- } \\
\text { ton et al. [75], Granek and Frasier [32], Tor et al. [92], Sigurdsson et al. [89], Costello et al. [41] }\end{array}$ \\
\hline Stomatopoda & To phylum only & $\begin{array}{l}\text { Zismann [94], Fincham [55], Meekan et al. [38], Carleton et al. [75], Granek and Frasier [32], Mwaluma et al. } \\
\text { [40], Tor et al. [92], Costello et al. [41] }\end{array}$ \\
\hline Tanaidacea & To phylum only & Zismann [94], Kawaguchi et al. [33], Granek and Frasier [32], Tor et al. [92], Costello et al. [41] \\
\hline Calanoida Copepoda & 29 & $\begin{array}{l}\text { Jones [46], Smith et al. [90], Tranter et al. [93], Kawaguchi et al. [33], Holmes and Jeal [82], Carleton et al. } \\
\text { [75], Hovda and Fosshagen [54], Tor et al. [92], Costello et al. [41] }\end{array}$ \\
\hline Other Copepoda & 15 & $\begin{array}{l}\text { Smith et al. [90], Tranter et al. [93], Gotto et al. [78], Kawaguchi et al. [33], Holmes and Jeal [82], Song and } \\
\text { Yun [91], Carleton et al. [75], Hovda and Fosshagen [54], Tor et al. [92], Chang [76], Costello et al. [41] }\end{array}$ \\
\hline Cirripedia & 1 & Jones [46], Carleton et al. [75], Granek and Frasier [32], Costello et al. [41] \\
\hline Ostracoda & 4 & $\begin{array}{l}\text { Zismann [94], Fincham [55], Smith et al. [90], Tranter et al. [93], Holmes and Jeal [82], Carleton et al. [75], } \\
\text { Granek and Frasier [32], Mwaluma et al. [40], Tor et al. [92], Costello et al. [41] }\end{array}$ \\
\hline
\end{tabular}



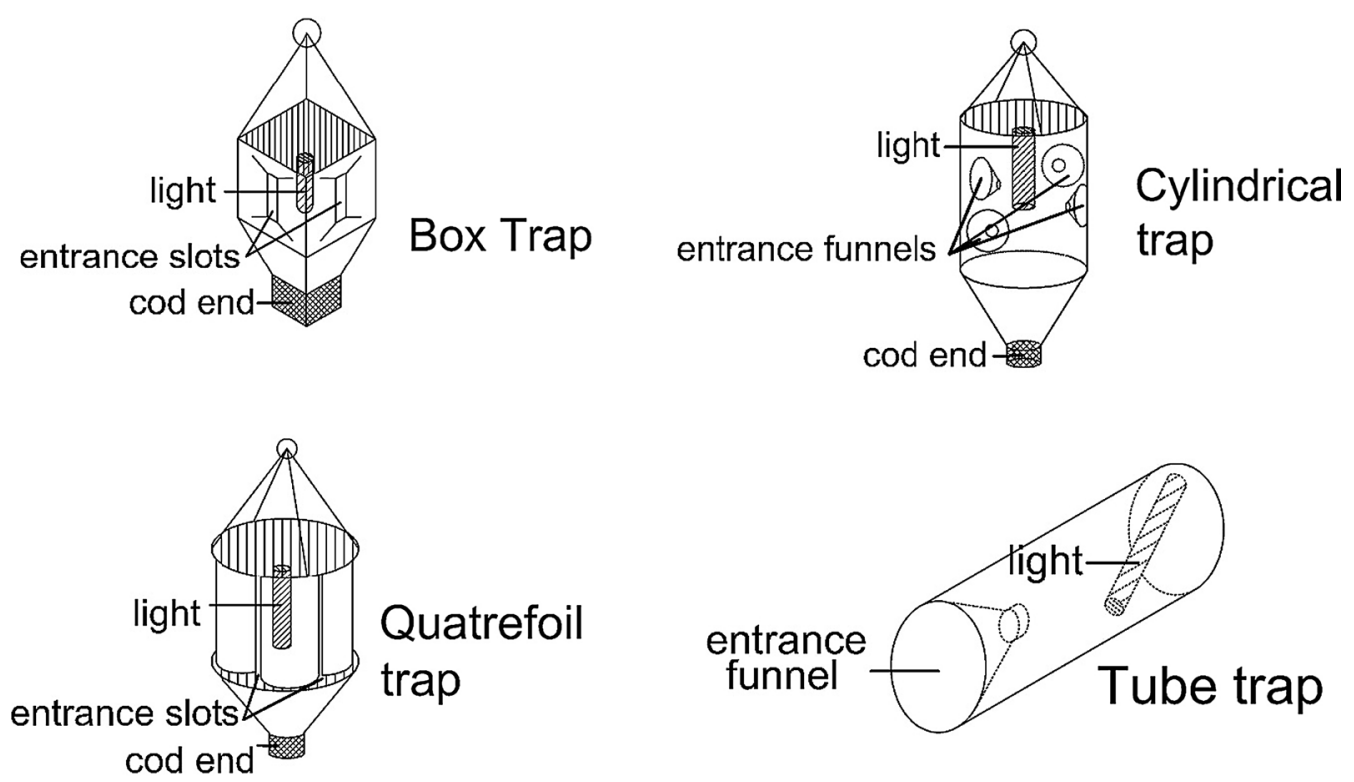

Fig. 1 Designs of light traps: box trap [23, 70-72]; cylindrical trap [38, 41]; quatrefoil trap [39, 64]; tube trap [33, 40, 41]. The percentage of publications using each type were 42,19,13 and 12\% respectively. Trap dimensions varied between about $30 \mathrm{~cm}$ in length (tube trap) to $1 \mathrm{~m}$ in height (other traps)

traps [40]. Only one study quantified animal escape from traps [38] and this is likely to be the case to some extent for all traps while deployed and during retrieval.

The quatrefoil and larger traps may need to be built in a workshop or purchased commercially. However, many others have also had success with low tech traps made from recycled water bottles [41, 42], jugs [30, 43], buckets [44], plastic bins [29], or simple tubes [34, 45]. Mesh traps, where the principle body of the trap is constructed of netting have also been employed [46-49]. However, animals attempting to enter the trap can clog the outside of the net and impede the transmittance of the light [22].

\section{Type of light}

The type of light used within a light trap can vary in colour, intensity and type. Traditionally fluorescent or incandescent bulbs have been used but chemical lights are also very common. The use of LED lights is on the rise and currently appears to be the best option as they are robust, inexpensive, and have low energy requirements (Table 4). The optimum brightness of illumination has not been studied. While Hale [50] observed a greater catch with lights of $26.9 \mathrm{~lm} \mathrm{~m}^{-2}$ than with very bright lights, comparative experiments were not reported. Blue, green and yellow coloured lights appear to have the highest catch rates [51-53] although this may be confounded with the intensity of the lights used. Red lights appear to have the least success. Since longer wavelengths are the first to be attenuated in water the lack of success with red lights seems likely to be due to a lower distance of illumination.

\section{Biases}

Light traps select for photo positive organisms. Since phototaxis can change during development light traps may target some life stages or even sexes more than others [53, 54]. In studying amphipods with light traps, Fincham [55] found that adult male benthic amphipods dominated light trap catches with juvenile and female presence varying throughout the lunar cycle and at times being absent. For larval fishes, light traps tend to catch larger (older) larvae than plankton nets and fewer individuals $[29,56]$. This may be due to their stronger swimming ability, greater attraction to light, or due to selective predation of smaller individuals within the trap [29, 56, 57]. However, Chicharo et al. [23] found three types of light trap to have similar and less variable catch than plankton nets for fish larvae. Vilizzi et al. [57] found lighttraps protected by a mesh had many more juveniles and larvae than the traps without a mesh. The gut content of fish in the mesh-less traps showed that one species in particular had been preying on larvae and juveniles. Similarly in freshwater, Ulrich [58] observed that insects were being eaten by fish as they approached a light-trap and that a cage around the trap was necessary to enhance the light trap's effectiveness. 
Table 4 Types of illumination used in light traps

\begin{tabular}{|c|c|c|c|}
\hline Light type & Advantages & Disadvantages & References \\
\hline LED & $\begin{array}{l}\text { Very energy efficient, robust, many } \\
\text { colours }\end{array}$ & Light is directional not 360 degrees & Gyekis et al. [79] \\
\hline $\begin{array}{l}\text { Chemical (Cyalume or } \\
\text { glow stick) }\end{array}$ & $\begin{array}{l}\text { Low failure rate, inexpensive, robust, } \\
\text { many colours, } 360 \text { degrees of light }\end{array}$ & $\begin{array}{l}\text { Light intensity is low and variable; light } \\
\text { intensity may be affected by tempera- } \\
\text { ture }\end{array}$ & $\begin{array}{l}\text { Barr [45], Holmes and O'Connor [72], } \\
\text { Kissick [73], Kehayias et al. [84], } \\
\text { Costello et al. [41] }\end{array}$ \\
\hline Incandescent & Widely available, 360 degrees of light & $\begin{array}{l}\text { Uses a lot of power, emits heat as well as } \\
\text { light, fragile }\end{array}$ & Faber [71], Floyd et al. [39] \\
\hline Fluorescent & Bright, energy efficient & Only one colour, fragile & $\begin{array}{l}\text { Aiken [74], Kawaguchi et al. [33], } \\
\text { Doherty [24] }\end{array}$ \\
\hline Halogen & Very bright & $\begin{array}{l}\text { Requires a lot of power, must be tethered } \\
\text { to large battery, produces heat, fragile }\end{array}$ & $\begin{array}{l}\text { Hernandez Jr and Shaw [64], Lindquist } \\
\text { and Shaw [86] }\end{array}$ \\
\hline
\end{tabular}

Table 5 Abiotic factors affecting light trap catch

\begin{tabular}{|c|c|c|}
\hline Abiotic factor examined & Results & References \\
\hline \multirow[t]{2}{*}{ Current } & $\begin{array}{l}\text { Light traps were not as effective in catching larval fish in a high current area as } \\
\text { opposed to a low current area }\end{array}$ & Anderson et al. [48] \\
\hline & Light traps that were allowed to float with current had higher catch rates & Thorrold [60] \\
\hline Turbidity & Catch rate decreased with increasing turbidity for larval fish & Lindquist and Shaw [86] \\
\hline \multirow{2}{*}{$\begin{array}{l}\text { Sampling duration, and time of day } \\
\text { and night }\end{array}$} & No difference in time of night catches for larval fish & Thorrold [60] \\
\hline & $\begin{array}{l}\text { There were two peaks in catch rates of invertebrates, one near dusk and one } \\
\text { near dawn }\end{array}$ & Tranter et al. [93] \\
\hline \multirow[t]{2}{*}{ Lunar cycle } & Highest catch rate at new moon and lowest catch rates at full moon & Hernandez Jr and Shaw [64] \\
\hline & $\begin{array}{l}\text { Highest catch rates at the third quarter moon (i.e., day 22-24 of the lunar cycle) } \\
\text { though not consistent for all species }\end{array}$ & Sponaugle and Cowen [47] \\
\hline \multirow[t]{2}{*}{ Depth of sample } & Highest invertebrate catch rates were found closest to the benthos & Tranter et al. [93], Tor et al. [92] \\
\hline & $\begin{array}{l}\text { For larval fish, catch rate varied with different species having peak catch rates at } \\
\text { different depths }\end{array}$ & Fisher and Bellwood [77] \\
\hline \multirow[t]{2}{*}{ Tidal effects } & No tidal effects & Chícharo et al. [23] \\
\hline & Highest catch rates at low tide & Beckley and Naidoo [70] \\
\hline
\end{tabular}

\section{Abiotic considerations}

Variability in light trap catch may be related to turbidity, current, sampling time, lunar cycle and time of year (Table 5). The turbidity affects the distance the light reaches and the composition of the water may affect what wavelengths are transmitted [59]. Increased current can lower catch rates $[40,42,60]$. Fast currents can make it impossible for less mobile species to reach or enter the trap, even if they are attracted by the light [48]. Currents may also affect the stability of a trap causing it to move or rotate which may impede entry into the trap. In our use of light traps for teaching, we found very few animals were captured in light traps deployed in tidal currents or moved by wave action.

Sampling times and duration are likely to affect catch composition. The diel vertical migration of plankton, and nocturnal emergence of benthic animals into the plankton [61-63] will affect the distribution of species in light trap samples. The tide may affect catch either through its effects on animal behaviour or on current speed and direction. The phase of the moon has been shown to affect catch rates, generally increasing catch at times when the moon is less bright, though its impact may differ between species [47, 64]. Fincham [55] found that early night catches of amphipods were dominated by infaunal species while in the hours before dawn amphipods that inhabited the algae made up the majority. However, sampling the whole night can result in greater predation within the traps [65]. Thus, further research is needed into the relative benefits of sampling for short periods or overnight.

\section{Recommendations}

Given the success of light traps in collecting marine fish and invertebrates, they merit investigation for monitoring marine invertebrate biodiversity, in particular for 
monitoring mobile benthic macrofauna which are difficult and time-consuming to sample by other means. This fauna is a key link between primary producers and high trophic level taxa, including commercially important fish. Monitoring the biodiversity of these macrofauna may prove even more important as their abundance may be affected in ways we do not yet realise. For example, due to the consumption of inedible plastics by plankton and/ or fishing-induced trophic cascades [66]. In addition, the traps capture a variety of life-stages of both benthic and pelagic taxa whereas other methods are selective for these environments.

The option of low cost light trap construction is another advantage over other sampling methods. The materials can be as simple as a water bottle and a light source, materials that can likely be found the world over. A bottle trap we used cost less than $\$ 5$ to build. The samples can also be taken passively, which means multiple locations can be sampled simultaneously giving a more complete picture of biodiversity over a large area. Finally the condition of the organisms which are collected is excellent which aids morphological identification. Specimens can be easily separated for archiving in reference collections, and samples could also be analysed by eDNA methods [3].

Light traps are limited to areas of low current and their effectiveness may be curbed by turbidity. However, it must be recognised that every sampling method is biased [3, 67]. To implement the use of light traps for monitoring benthic biodiversity the design, biases and abiotic factors need further research. Given the potential efficiency of the quatrefoil trap it may prove to capture most animals. However, such abundance may come at a higher cost of construction. The type of light used in this trap could vary, but for robustness and cost either an LED light or a chemical light would be the best choice. Small traps of 1-2 L volume appear adequate. Sampling all night may avoid missing out on nocturnal variation in species' abundance, but sampling for 1-2 $\mathrm{h}$ after dusk may be more time efficient and reduce within trap predation. A shorter sampling time period would also help staff monitor traps where disturbance by changing weather conditions or curious members of the public may be a concern. As current and turbidity are known to affect catch rates, recording these measurements would be useful in interpreting any catch results. Simple lowcost methods for monitoring these conditions also merit development. Further investigation into between-sample variation is also needed to understand how well the catch of light traps reflect the biodiversity in a given location, and how many replicates are required for each sampling occasion.
Biodiversity monitoring needs methods that can be standardised internationally, are low cost, easy to use, and produce verifiable data on species composition and relative abundance. With further research to understand how factors may influence light trap catches at local scales, they are a promising method for mobile benthic macrofauna and zooplankton. They would thus complement emerging non-destructive methods for sampling fish and other vertebrates (e.g., using video and direct observations), and emerging methods for using artificial substrata to census sedentary and sessile biota $[3,68,69]$.

\section{Additional file}

Additional file 1. Tables listing the invertebrate and fish taxa captured in light traps, and associated references

\section{Authors' contributions}

LEM conducted the literature review, compiled the data, and led writing of the paper. MJC initiated the study, advised on the data analysis, and co-wrote the paper. Both authors read and approved the final manuscript.

\section{Acknowledgements}

We thank Louise Franklin, Antje Lisken-Kleinmans, David Fields, Bill Sanderson, Emanuel Gonçalves, Emmett Duffy and Mark Holmes for helpful discussion and information on literature and their experience using light traps, Islay Marsden for information on light traps used by students, and Liam Kelly Costello for assistance with reference formatting.

\section{Competing interests}

The authors declare that they have no competing interests.

\section{Availability of data and materials}

All data generated or analysed during this study are included in this published article and its Additional file 1.

Received: 16 March 2016 Accepted: 20 January 2017

Published online: 08 February 2017

\section{References}

1. Andréfouët $S$, Costello MJ, Faith DP, Ferrier S, Geller GN, Höft R, Jürgens N, Lane MA, Larigauderie A, Mace G, Miazza S, Muchoney D, Parr T, Pereira HM, Sayre R, Scholes RJ, Stiassny ML, Turner W, Walther BA, Yahara T. The GEO biodiversity observation network concept document. Geneva: GEOGroup on Earth Observations; 2008.

2. Pereira HM, Ferrier S, Walters M, Geller G, Jongman R, Scholes R, Bruford MW, Brummitt N, Butchart S, Cardoso A. Essential biodiversity variables. Science. 2013;339(6117):277-8.

3. Costello MJ, Basher Z, McLeod L, Assad I, Claus S, Vandepitte L, Yasuhara M, Gislason H, Edwards M, Appeltans W, Enevoldsen H, Edgar G, Miloslavich P, de Monte S, Sousa Pinto I, Obura D, Bates A. Methods for the study of marine biodiversity. In: Scholes RJ, Walters M, editors. GEO handbook on biodiversity observation networks. Berlin: Springer; 2016.

4. Schipper AM, Belmaker J, Miranda MD, Navarro LM, Böhning-Gaese K, Costello MJ, Dornelas M, Foppen R, Hortal J, Huijbregts MAJ, MartínLópez B, Pettorelli N, Queiroz C, Rossberg AG, Santini L, Schiffers K, Steinmann ZJN, Visconti P, Rondinini C, Pereira HM. Contrasting changes in the abundance and diversity of North American bird assemblages from 1971 to 2010. Glob Change Biol. 2016;22(12):3948-59. 
5. OBIS. Data from the Ocean Biogeographic Information System (Intergovernmental oceanographic commission of UNESCO). 2015. Retrieved 2015-10-07. http://www.iobis.org.

6. Richardson AJ, Walne AW, John AWG, Jonas TD, Lindley JA, Sims DW, Stevens D, Witt M. Using continuous plankton recorder data. Prog Oceanogr. 2006;68(1):27-74.

7. Melrose C. Continuous Plankton Recorder Dataset (NOAA)—Zooplankton. In: OBIS (2015). Data from the Ocean Biogeographic Information System (Intergovernmental Oceanographic Commission of UNESCO) 2010. Retrieved 2015-10-07. http://www.iobis.org.

8. Stevens D. Continuous Plankton Recorder Dataset (SAHFOS)_-Pacific Zooplankton. OBIS (2015). Data from the Ocean Biogeographic Information System (Intergovernmental oceanographic commission of UNESCO). 2010. Retrieved 2015-10-07. http://www.iobis.org.

9. Stevens D. Continous Plankton Recorder (zooplankton). In: OBIS (2015). Data from the Ocean Biogeographic Information System (Intergovernmental Oceanographic Commission of UNESCO). 2011. Retrieved 201510-07. http://www.iobis.org.

10. Hicklin PW, Smith PC. The diets of five species of migrant shorebirds in the Bay of Fundy. Proc N S Inst Sci. 1976;29:483-8.

11. Russell BC. The food and feeding habits of rocky reef fish of north-eastern New Zealand. N Z J Mar Freshw Res. 1983;17(2):121-45. doi:10.1080/0028 8330.1983.9515991.

12. Usmar NR. Ontogenetic diet shifts in snapper (Pagrus auratus: Sparidae) within a New Zealand estuary. NZ J Mar Freshw Res. 2012;46(1):31-46.

13. Elliott M, Hemingway K, Costello MJ, Duhamel S, Hostens K, Labropoulou M, Marshall S, Winkler H. Links between fish and other trophic levels. In: Elliott M, Hemingway K, editors. Fishes in estuaries. Oxford: Blackwell Science; 2002. p. 124-216.

14. Zeldis J, Robinson K, Ross A, Hayden B. First observations of predation by New Zealand Greenshell mussels (Perna canaliculus) on zooplankton. J Exp Mar Biol Ecol. 2004;311(2):287-99.

15. Costello MJ, Beard KH, Corlett RT, Cumming GS, Devictor V, Loyola R, Maas B, Miller-Rushing AJ, Pakeman R, Primack RB. Field work ethics in biological research. Biol Conserv. 2016;203:268-71.

16. Szentkiralyi F. Fifty year long insect survey in Hungary: T. Jermy's contributions to light-trapping. Acta Zool Acad Sci Hung. 2002;1:85-105.

17. Mulhern TD. New Jersey mechanical trap for mosquito surveys. 1942. J Am Mosq Control Assoc. 1985;1 (4):411-8.

18. Frost SW. The Pennsylvania insect light trap. J Econ Entomol. 1957;50(3):287-92.

19. Sudia WD, Chamberlain RW. Battery-operated light trap, an improved model. By W. D. Sudia and R. W. Chamberlain, 1962. J Am Mosq Control Assoc. 1988:4(4):536-8.

20. Frost SW. Insects taken in light traps at the Archibold Biological Station, Highlands County, Florida. Fla Entomol. 1964:47(2):129-61.

21. Williams CB. The Rothamsted light-trap. Proc R Entomol Soc Lond Ser A. 1948;23(7-9):80-5.

22. Brogan MW. Two methods of sampling fish larvae over reefs: a comparison from the Gulf of California. Mar Biol. 1994;1 18(1):33-44.

23. Chícharo L, Faria A, Morais P, Amaral A, Mendes C, Chícharo MA. How to sample larval fish for taxonomical and ecophysiological studies in shallower temperate coastal ecosystems? Cah Biol Mar. 2009:50(4):311-8.

24. Doherty PJ. Light-traps: selective but useful devices for quantifying the distributions and abundances of larval fishes. Bull Mar Sci. 1987;41(2):423-31.

25. Novales Flamarique I, Gulbransen C, Galbraith M, Stucchi D. Monitoring and potential control of sea lice using an LED-based light trap. Can J Fish Aquat Sci. 2009;66(8):1371-82. doi:10.1139/f09-094.

26. Pahl BC, Cole DG, Bayer RC. Sea lice control. I: description of a low maintenance, photomechanical device for use as an alternate control for sea lice, Lepeophtheirus salmonis, in marine aquaculture. J Appl Aquac. 1999;9(1):85-96.

27. Rae GH. Sea louse control in Scotland, past and present. Pest Manag Sci. 2002;58(6):515-20.

28. Costello MJ. Ecology of sea lice parasitic on farmed and wild fish. Trends Parasitol. 2006;22(10):475-83.

29. Hickford MJH, Schiel DR. Evaluation of the performance of light traps for sampling fish larvae in inshore temperate waters. Mar Ecol Prog Ser. 1999;186:293-302.
30. Roegner GC, Armstrong DA, Hickey BM, Shanks AL. Ocean distribution of Dungeness crab megalopae and recruitment patterns to estuaries in Southern Washington State. Estuaries. 2003;26(4):1058-70.

31. Strydom NA. An assessment of habitat use by larval fishes in a warm temperate estuarine creek using light traps. Estuaries. 2003;26(5):1310-8. doi:10.2307/1353405

32. Granek EF, Frasier K. The impacts of red mangrove (Rhizophora mangle) deforestation on zooplankton communities in Bocas del Toro, Panama. Bull Mar Sci. 2007:80(3):905-14.

33. Kawaguchi K, Matsuda O, Ishikawa S, Naito Y. A light trap to collect krill and other micronektonic and planktonic animals under the Antarctic coastal fast ice. Polar Biol. 1986;6(1):37-42.

34. Øresland V. Description of the IMR standard light trap and the vertical distribution of some decapod larvae (Homarus and Nephrops). West Indian Ocean J Mar Sci. 2007;6(2):225-31.

35. Shanks AL, Roegner GC. Recruitment limitation in Dungeness crab populations is driven by variation in atmospheric forcing. Ecology. 2007:88(7):1726-37. doi:10.1890/06-1003.1.

36. Meekan MG, Wilson SG, Halford A, Retzel A. A comparison of catches of fishes and invertebrates by two light trap designs, in tropical NW Australia. Mar Biol. 2001;139(2):373-81.

37. Aiken RB, Roughley RE. An effective trapping and marking method for aquatic beetles. Proc Acad Nat Sci Phila. 1985;137(1):5-7. doi:10.2307/4064874

38. Meekan MG, Doherty PJ, White $L \mathrm{~J}$ r. Recapture experiments show the low sampling efficiency of light traps. Bull Mar Sci. 2000;67(3):875-85.

39. Floyd KB, Courtenay WH, Hoyt RD. A new larval fish light trap: the quatrefoil trap. Progres Fish Cult. 1984;46(3):216-9.

40. Mwaluma JM, Kaunda-Arara B, Osore MK, Rasowo J. A cost effective light trap for sampling tropical fish and crustacean larvae. West Indian Ocean J Mar Sci. 2009:8(2):231-7.

41. Costello M, Lisken-Kleinmans A, Franklin L, McLeod L. Sampling mobile macroinvertebrates: a role for light-traps? ScienceOpen Posters. 2015; doi:10.14293/P2199-8442.1.SOP-LIFE.PGZJJR.v1.

42. Shaw RF, Cope JS, Holt GJ, Röpke A, Thorrold SR, Ditty JG, Faroogi TW, Rooker JR. Comparison of plankton catch by three light-trap designs in the northern Gulf of Mexico. Gulf M Sci. 2007;25(2):109-18.

43. Michel L, Dauby P, Lepoint G, Sturaro N. Sampling methods for amphipods of Posidonia oceanica meadows: a comparative study. Crustaceana. 2010:83(1):39-47. doi:10.1163/156854009×454630.

44. Jones DL. Design, construction, and use of a new light trap for sampling larval coral reef fishes. NOAA Technical Memorandum, NMFS-SEFSC-544; 2006

45. Barr D. Water mites (Acari, Parasitengona) sampled with chemoluminescent bait in underwater traps. Int J Acarol. 1979;5(3):187-94.

46. Jones DA. A new light trap for plankton. In: Crisp DJ, editor. Fourth European marine biology symposium. Bangor: Cambridge University Press; 1971. p. 487-93.

47. Sponaugle S, Cowen RK. Nearshore patterns of coral reef fish larval supply to Barbados, West Indies. Mar Ecol Prog Ser. 1996;133(1-3):13-28.

48. Anderson TW, Bartels CT, Hixon MA, Bartels E, Carr MH, Shenker JM. Current velocity and catch efficiency in sampling settlement-stage larvae of coral-reef fishes. Fish Bull. 2002;100(3):404-13.

49. Ahmadi. An introduction of light traps for sampling freshwater shrimp and fish in the Barito River, South Kalimantan. J Fish Aquat Sci. 2012:7(2):173-82.

50. Hale HM. Notes on distribution and night collecting with artificial light. Trans R Soc S Aust. 1953:70:70-6.

51. Marchetti MP, Esteban E, Limm M, Kurth R. Evaluating aspects of larval light trap bias and specificity in the Northern Sacramento river system: do size and color matter? Am Fish Soc Symp. 2004;2004(39):269-79.

52. Kehayias $G$, Doulka E. A light trap for sampling Atherina boyeri larvae in Lake Trichonis, Greece. J Freshw Ecol. 2007:22(3):533-4.

53. Gehrke PC. Influence of light intensity and wavelength on phototactic behaviour of larval silver perch Bidyanus bidyanus and golden perch Macquaria ambigua and the effectiveness of light traps. J Fish Biol. 1994:44(5):741-51.

54. Hovda Jl, Fosshagen A. Hyperbenthic calanoids and Thespesiopsyllus paradoxus (Sars) collected with a light trap in western Norway. Sarsia. 2003:88(1):89-94. 
55. Fincham AA. Periodic swimming behaviour of amphipods in Wellington Harbour. N Z J Mar Freshwat Res. 1974;8(3):505-21. doi:10.1080/00288330. 1974.9515521.

56. Choat JH, Doherty PJ, Kerrigan BA, Leis JM. A comparison of towed nets, purse seine, and light-aggregation devices for sampling larvae and pelagic juveniles of coral reef fishes. Fish Bull. 1993;91(2):195-209.

57. Vilizzi L, Meredith SN, Sharpe CP, Rehwinkel R. Evaluating light trap efficiency by application of mesh to prevent inter- and intra-specific in situ predation on fish larvae and juveniles. Fish Res. 2008;93(1-2):146-53.

58. Ulrich GW. Construction of a compact submersible aquatic light trap. Pan Pac Entomol. 1986:62(2):144-9.

59. Gallegos CL, Correll DL, Pierce JW. Modeling spectral diffuse attenuation, absorption, and scattering coefficients in a turbid estuary. Limnol Oceanogr. 1990;35(7):1486-502. doi:10.4319/lo.1990.35.7.1486.

60. Thorrold SR. Evaluating the performance of light traps for sampling small fish and squid in open waters of the central Great Barrier Reef lagoon. Mar Ecol Prog Ser. 1992;89(2-3):277-85.

61. Cushing DH. The vertical migration of planktonic Crustacea. Biol Rev. 1951;26(2):158-92.

62. Haney JF. Diel patterns of zooplankton behavior. Bull Mar Sci. 1988;43(3):583-603.

63. Hays GC. A review of the adaptive significance and ecosystem consequences of zooplankton diel vertical migrations. Hydrobiologia. 2003;503:163-70

64. Hernandez FJ Jr, Shaw RF. Comparison of plankton net and light trap methodologies for sampling larval and juvenile fishes at offshore petroleum platforms and a coastal jetty off Louisiana. Am Fish Soc Symp. 2003;2003(36):15-38.

65. Ruck JG. A light-trap for collecting marine fish larvae and invertebrates. Tuatara J Biol Soc. 1975;21(3):98-104.

66. Leleu K, Remy-Zephir B, Grace R, Costello MJ. Mapping habitats in a marine reserve showed how a 30-year trophic cascade altered ecosystem structure. Biol Conserv. 2012;155:193-201. doi:10.1016/j. biocon.2012.05.009

67. Rozas LP, Minello TJ. Estimating densities of small fishes and decapod crustaceans in shallow estuarine habitats: a review of sampling design with focus on gear selection. Estuaries. 1997;20(1):199-213.

68. Costello MI, Thrush SF. Colonization of artificial substrata as a multispecies bioassay of marine environmental quality. In: Jeffrey DW, Madden B, editors. Bioindicators and environmental management. London: Academic Press; 1991. p. 401-18

69. Leray M, Knowlton N. DNA barcoding and metabarcoding of standardized samples reveal patterns of marine benthic diversity. Proc Natl Acad Sci. 2015;112(7):2076-81.

70. Beckley LE, Naidoo AK. Exploratory trials with light-traps to investigate settlement stage fishes in subtropical, coastal waters off South Africa. Afr Zool. 2003;38(2):333-42.

71. Faber DJ. A light trap to sample littoral and limnetic regions of lakes. Verhandlungen Internationale Vereinigung für Theoretische und Angewandte Limnologie. 1981;21:776-81.

72. Holmes JMC, O'Connor JP. A portable light-trap for collecting marine crustaceans. J Mar Biol Assoc UK. 1988;68(2):235-8.

73. Kissick LA. Comparison of traps lighted by photochemicals or electric bulbs for sampling warm water populations of young fish. N Am J Fish Manag. 1993;13(4):864-7. doi:10.1577/1548-8675(1993)013<0864:COTLB P>2.3.CO;2.

74. Aiken R. A size selective underwater light trap. Hydrobiologia. 1979;65(1):65-8

75. Carleton JH, Brinkman R, Doherty PJ. Zooplankton community structure and water flow in the lee of Helix Reef (Great Barrier Reef, Australia). Mar Biol. 2001;139(4):705-17.

76. Chang CY. First record of monstrilloid copepods in Korea. Anim Syst Evol Divers. 2012;28(2):126-32

77. Fisher R, Bellwood DR. A light trap design for stratum-specific sampling of reef fish larvae. J Exp Mar Biol Ecol. 2002;269(1):27-37
78. Gotto RV, Holmes JMC, Lowther RP. Description of the adult male Mychophilus roseus Hesse (Copepoda: Cyclopoida): a copepod with remarkable sensory equipment. Ir Nat J. 1984;21(7):305-13. doi:10.2307/25538828.

79. Gyekis KF, Cooper MJ, Uzarski DG. A high-intensity LED light source for larval fish and aquatic invertebrate floating quatrefoil light traps. J Freshw Ecol. 2006;21(4):621-6.

80. Hale HM. Notes on two sand-dwelling Cumacea (Gephyrocuma and Picrocuma). Rec S Aust Mus. 1943;7(4):337-42.

81. Herter H, Eckert GL. Transport of Dungeness crab Cancer magister megalopae into Glacier Bay, Alaska. Mar Ecol Prog Ser. 2008;372:181-94.

82. Holmes JMC, Jeal F. Some crustaceans associated with the gribble Limnoria lignorum (Rathke) in Ireland. Ir Nat J. 1987;22(7):317-9. doi:10.2307/25539179.

83. Jackson GD, Meekan MG, Wotherspoon S, Jackson CH. Distributions of young cephalopods in the tropical waters of Western Australia over two consecutive summers. ICES J Mar Sci. 2008:65(2):140-7.

84. Kehayias G, Antonou M, Zerva M, Karachalios I. Using plankton nets as light traps: application with chemical light. J Plankton Res. 2008;30(9):1075-8. doi:10.1093/plankt/fbn060.

85. Kim Y-H, Hendrycks EA, Lee K-S. New genera and species of the Synchelidium group (Amphipoda: Oedicerotidae) from Asia-North Pacific. J Nat Hist. 2012;46(37-38):2349-76. doi:10.1080/00222933.2012.713526.

86. Lindquist DC, Shaw RF. Effects of current speed and turbidity on stationary light-trap catches of larval and juvenile fishes. Fish Bull. 2005;103(2):438-44.

87. Porter SS, Eckert GL, Byron CJ, Fisher JL. Comparison of light traps and plankton tows for sampling brachyuran crab larvae in an Alaskan Fjord. J Crustac Biol. 2008;28(1):175-9.

88. Sale PF, McWilliam PS, Anderson DT. Faunal relationships among the near-reef zooplankton at three locations on heron reef, Great Barrier Reef, and seasonal changes in this fauna. Mar Biol. 1978;49(2):133-45. doi:10.1007/BF00387113.

89. Sigurdsson GM, Morse B, Rochette R. Light traps as a tool to sample pelagic larvae of American lobster (Homarus americanus). J Crustac Biol. 2014;34(2):182-8.

90. Smith DF, Bulleid NC, Campbell R, Higgins HW, Rowe F, Tranter DJ, Tranter $\mathrm{H}$. Marine food-web analysis: an experimental study of demersal zooplankton using isotopically labelled prey species. Mar Biol. 1979;54(1):49_ 59. doi:10.1007/BF00387051.

91. Song SJ, Yun SG. A new species of the Peltidium quinquesetosum (Copepoda: Harpacticoida: Peltidiidae) on the marine macroalgae in Korea. Korean J Syst Zool. 1999:15(1):67-74.

92. Tor A, Deudero S, Carbonell A, Goñi R, Stobart B. Coastal meroplanktonic larval stages of peninsula de Llevant natural reserve determined with light traps. Bolleti de la Societat d'Historia Natural de les Balears. 2010;53:193-202

93. Tranter DJ, Bulleid NC, Campbell R, Higgins HW, Rowe F, Tranter HA, Smith DF. Nocturnal movements of phototactic zooplankton in shallow waters. Mar Biol. 1981:61(4):317-26.

94. Zismann L. A light-trap for sampling aquatic organisms. Isr J Zool. 1969;18(4):343-8.

\section{Submit your next manuscript to BioMed Central and we will help you at every step:}

- We accept pre-submission inquiries

- Our selector tool helps you to find the most relevant journal

- We provide round the clock customer support

- Convenient online submission

- Thorough peer review

- Inclusion in PubMed and all major indexing services

- Maximum visibility for your research

Submit your manuscript at www.biomedcentral com/submit 